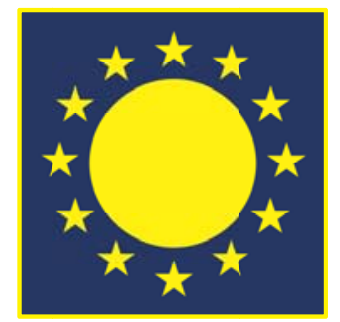

\title{
32nd European Photovoltaic Solar Energy Conference and Exhibition
}

Proceedings of the International Conference held in Munich, Germany

20 June - 24 June 2016

Edited by.

M. TOPIČ

University of Ljubljana

Chairman of European Technology \& Innovation Platform Photovoltaics

Ljubljana, Slovenia

N. TAYLOR

European Commission - DG Joint Research Centre

Ispra, Italy

P. HELM

WIP Renewable Energies

Munich, Germany

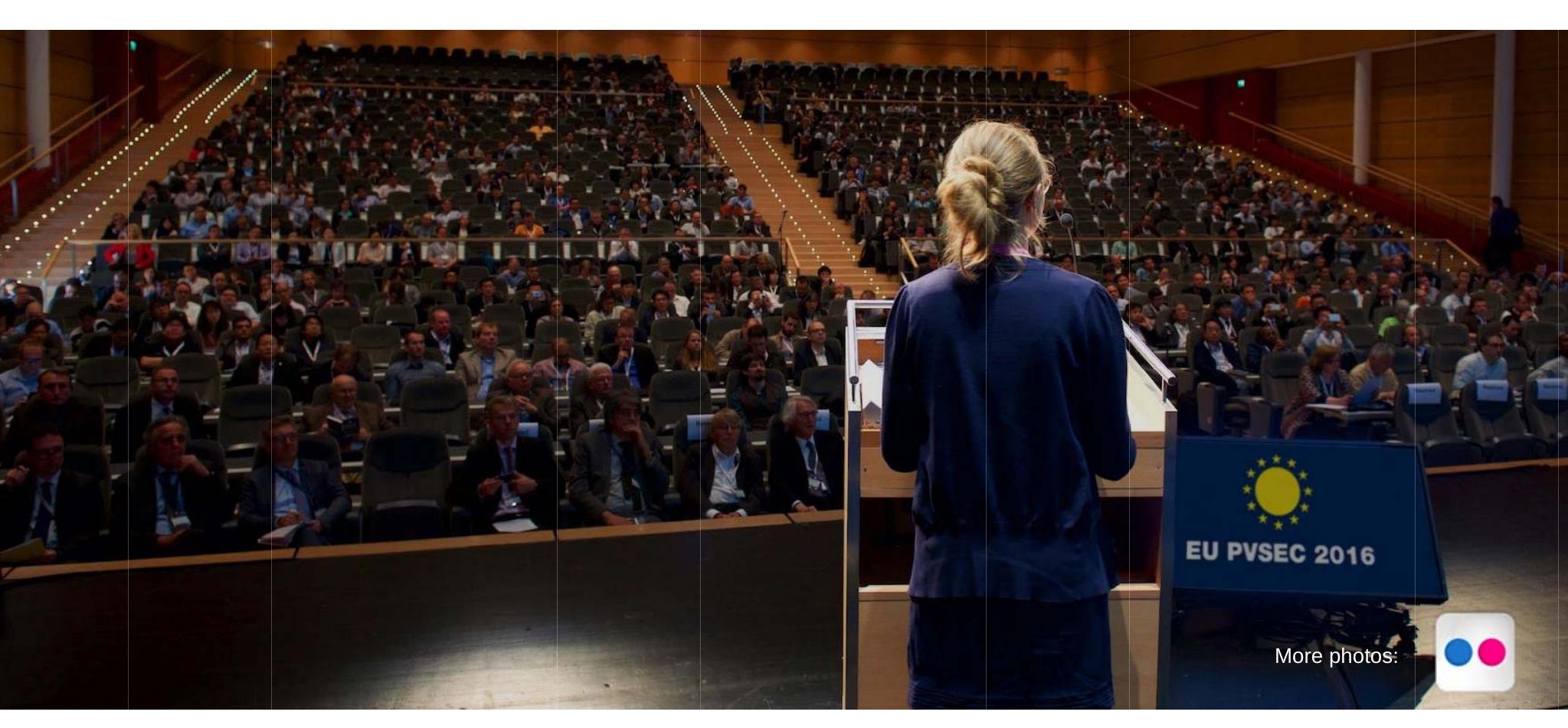




\section{Institutional Support:}

European Commission

UNESCO - United Nations Educational, Scientific and Cultural Organization, Natural Sciences Sector WCRE - World Council for Renewable Energy

\section{Supporting Organisations:}

ARE - Alliance for Rural Electrification

EREF - European Renewable Energies Federation

ESA - European Space Agency

EUFORES - The European Forum for Renewable Energy Sources

EUREC - The Association of European Renewable Energy Research Centres

European Photovoltaic Technology Platform

IEA PVPS - International Energy Agency Photovoltaic Power Systems Programme

REN21 - Renewable Energy Policy Network for the 21st Century

\section{Institutional PV Industry Cooperation:}

SolarPower Europe

SOLARUNITED

\section{Supporting Associations:}

AIE - European Association of Electrical Contractors

AREA - African Renewable Energy Alliance

CABA - Continental Automated Buildings Association

EPIC - European Photonics Industry Consortium

SASIA - Saudi Arabia Solar Industry Association

\section{EU PVSEC realised by:}

WIP

Sylvensteinstr. 2, 81369 München, Germany

Tel: +49 8972012 735, Fax: +49 8972012791

Email: pv.conference@wip-munich.de

www.photovoltaic-conference.com

www.wip-munich.de

\section{Proceedings produced and published by:}

WIP

Sylvensteinstr. 2, 81369 München, Germany

Tel: +49 8972012 735, Fax: +49 8972012791

Email:pv.conference@wip-munich.de

www.photovoltaic-conference.com

www.wip-munich.de

\section{Legal notice}

Neither the European Commission, the Organiser or the Publisher nor any person acting on their behalf is responsible for the use which might be made of the following information.

\section{(C) 2016 WIP}

All rights reserved. No part of this publication may be reproduced in any form or by any electronic or mechanical means, including photocopying, recording or by any information storage and retrieval system without permission in writing from the copyright holder and the publisher.

Despite due diligence no liability for accuracy and completeness of the information and material offered in this document can be assumed by WIP. 


\section{2nd EUROPEAN PHOTOVOLTAIC SOLAR ENERGY CONFERENCE AND EXHIBITION \\ 20 JUNE - 24 JUNE 2016 \\ MUNICH, GERMANY}

EU PVSEC COMMITTEES

\section{INTERNATIONAL SCIENTIFIC ADVISORY COMMITTEE (ISAC)}

\section{Chair}

G.F. De Santi, European Commission, DG JRC, Director of the Institute for Energy and Transport, Ispra, Italy

\section{Secretary}

N. Taylor, European Commission, DG JRC, Institute for Energy and Transport, Ispra, Italy

\section{Committee Members}

P. Frankl, Head of the Renewable Energy Division, International Energy Agency, France

P. Hofer-Noser, CTO, Meyer Burger Technology, Switzerland

P. Malbranche, CEA, Le Bourget du Lac, France

S. Nowak, Managing Director of NET Nowak Energy \& Technology, Switzerland

W. Sinke, Program Development Manager, ECN Solar Energy, The Netherlands

P. Verlinden, Chief Scientific and Vice Chair, State Key Lab. TRINA Solar, China

E. Weber, Director, Fraunhofer ISE, Germany

P. Helm, WIP, Munich, Germany

A. Grassi, ETA-Florence Renewable Energies, Florence, Italy

\section{CONFERENCE EXECUTIVE COMMITTEE}

\section{Conference General Chairman}

M. Topič, University of Ljubljana, Chairman of European

Technology \& Innovation Platform Photovoltaics,

Ljubljana, Slovenia

\section{Technical Programme Chairman}

N. Taylor, European Commission, DG JRC, Institute for Energy and Transport, Ispra, Italy

\section{Committee Members}

H. Ossenbrink, European Commission, DG JRC, Institute for Energy and Transport, Ispra, Italy

S. Nowak, Managing Director of NET Nowak Energy \& Technology, St. Ursen, Switzerland

W. Sinke, Program Development Manager, ECN Solar Energy, The Netherlands

P. Helm, WIP, Munich, Germany

A. Grassi, ETA-Florence Renewable Energies, Florence, Italy

\section{SCIENTIFIC COMMITTEE \\ Topic Organisers and Paper Review Experts}

Topic 1 - New Materials and Concepts for Solar Cells and Modules

G. Beaucarne, Dow Corning, Seneffe, Belgium

N.J. Ekins-Daukes, Imperial College London, United Kingdom

A. Martí Vega, UPM, Madrid, Spain

J. Poortmans, imec, Leuven, Belgium

M. Rusu, HZB, Berlin, Germany

J.A.M. Van Roosmalen, ECN, Petten, Netherlands

V. Bukauskas, Center for Physical Sciences and Technology, Vilnius, Lithuania

F. Falk, IPHT, Jena, Germany

J. Govaerts, imec, Leuven, Belgium

J.F. Guillemoles, CNRS, Chatou Cedex, France

M.A. Hernandez-Fenollosa, UPV, Valencia, Spain

J.C. Hummelen, University of Groningen, Netherlands

D. König, UNSW, Sydney, Australia

I. Konovalov, Ernst Abbe University of Applied Science Jena, Jena, Germany

C. Lévy-Clément, CNRS, Thiais, France

Y. Okada, University of Tokyo, Japan

B. Rech, HZB, Berlin, Germany

F. Roca, ENEA, Portici, Italy

V. Saly, Slovak University of Technology, Bratislava, Slovakia

H. Shirai, Saitama University, Japan

W. Warta, Fraunhofer ISE, Freiburg, Germany

\section{Topic 2 - Wafer-Based Silicon Solar Cells and Materials} Technology

O. Anspach, PV Crystalox Solar, Erfurt, Germany

D.L. Bätzner, Meyer Burger Research, Hauterive, Switzerland

R. Brendel, ISFH, Emmerthal, Germany

F. Ferrazza, Eni, San Donato Milanese, Italy

S.W. Glunz, Fraunhofer ISE, Freiburg, Germany

G. Hahn, University of Konstanz, Germany

D. Muñoz, CEA, Le Bourget du Lac, France

S. Riepe, Fraunhofer ISE, Freiburg, Germany

A.W. Weeber, ECN, Petten, Netherlands

P. Wohlfart, Singulus Technologies, Kahl am Main, Germany

A.G. Aberle, SERIS, Singapore

N. Azkona, UPV/EHU, Zamudio, Spain

J. Bagdahn, Fraunhofer CSP, Halle (Saale), Germany

R. Barinka, Fill Factory, Rožnov pod Radhoštm, Czech Republic

P.A. Basore, PV Specialist Services, Solana Beach, USA 
D. Biro, Fraunhofer ISE, Freiburg, Germany

S. Bowden, Arizona State University, Tempe, USA

T.M. Bruton, TMB Consulting, Woking, United Kingdom

B. Dauksher, Arizona State University, Tempe, USA

M. Debucquoy, imec, Leuven, Belgium

T. Desrues, CEA, Le Bourget du Lac, France

D. Dimova-Malinovska, Bulgarian Academy of Sciences, Sofia, Bulgaria

S. Dubois, CEA, Le Bourget du Lac, France

T. Dullweber, ISFH, Emmerthal, Germany

P. Fath, RCT-Solutions, Konstanz, Germany

A.J. Galdikas, Modernios E-Technologijos, Vilnius, Lithuania

M. Hermle, Fraunhofer ISE, Freiburg, Germany

K. Hesse, Wacker Chemie, Burghausen, Germany

J. Horzel, CSEM, Neuchâtel, Switzerland

J. John, imec, Leuven, Belgium

S.D. Kim, SunPower, San Jose, USA

J. Libal, ISC Konstanz, Germany

A. Metz, h.a.l.m. elektronik, Frankfurt am Main, Germany

J.W. Müller, Hanwha Q CELLS, Bitterfeld-Wolfen, Germany

Y. Ohshita,TTI, Nagoya, Japan

S. Peters, Hanwha Q CELLS, Bitterfeld-Wolfen, Germany

K. Petter, Hanwha Q CELLS, Bitterfeld-Wolfen, Germany

R. Preu, Fraunhofer ISE, Freiburg, Germany

J. Rentsch, Fraunhofer ISE, Freiburg, Germany

E. Sauar, Brighterlite, Oslo, Norway

H. Schlemm, Meyer Burger, Hohenstein-Ernstthal, Germany

M.C. Schubert, Fraunhofer ISE, Freiburg, Germany

B. Terheiden, University of Konstanz, Germany

Y. Veschetti, CEA, Le Bourget du Lac, France

G.P. Willeke, Fraunhofer ISE, Freiburg, Germany

D. Wood, Hemlock Semiconductor, Hemlock, USA

A. Yamada, Tokyo Institute of Technology, Japan

D.L. Young, NREL, Golden, USA

\section{Topic 3 - Thin Film Solar Cells and Modules}

C.J. Brabec, University of Erlangen-Nuremberg, Germany

J. Cárabe, CIEMAT, Madrid, Spain

A. Meeder, Flisom, Dübendorf, Switzerland

J. Meier, PV Consultant, Berlingen, Switzerland

S. Siebentritt, University of Luxembourg, Belvaux, Luxembourg

M. Topic, University of Ljubljana, Slovenia

S.C. Veenstra, ECN, Eindhoven, Netherlands

W. Wischmann, ZSW, Stuttgart, Germany

C. Ballif, EPFL\&CSEM, Neuchâtel, Switzerland

R. Birkmire, University of Delaware, Newark, USA

D. Cheyns, imec, Leuven, Belgium

S. Cros, CEA, Le Bourget du Lac, France

T. Dalibor, AVANCIS, Munich, Germany

P. Delli Veneri, ENEA, Portici, Italy

B. Dimmler, Manz CIGS Technology, Schwäbisch Hall, Germany

K. Durose, Stephenson Institute for Renewable Energy,

Liverpool, United Kingdom

S. Gall, HZB, Berlin, Germany

I. Gordon, imec, Leuven, Belgium

S. Huang, UNSW, Sydney, Australia

S.J.C. Irvine, Swansea University, St. Asaph, United Kingdom

R. Klenk, HZB, Berlin, Germany

C.-F. Lin, NTU, Taipei, Taiwan

M.C. Lux-Steiner, HZB, Berlin, Germany

E. Mellikov, Tallinn University of Technology, Tallinn, Estonia
M. Meuris, imec/IMOMEC - ATFPV, Leuven, Belgium

C. Molpeceres, UPM, Madrid, Spain

J. Parisi, University of Oldenburg, Oldenburg, Germany

R. Po, Eni, Novara, Italy

M. Powalla, ZSW, Stuttgart, Germany

A. Romeo, University of Verona, Verona, Italy

V. Sittinger, Fraunhofer IST, Braunschweig, Germany

A. Slaoui, InESS, Strasbourg, France

A.N. Tiwari, EMPA, Dübendorf, Switzerland

A. Virtuani, SUPSI, Canobbio, Switzerland

M. Zeman, Delft University of Technology, Netherlands

\section{Topic 4 - Concentrator and Space Applications}

R. Campesato, CESI, Milan, Italy

G. Flamand, imec, Leuven, Belgium

F. Rubio Berenguel, Freiburg, Germany

C. Signorini, ESA-ESTEC, Noordwijk, Netherlands

I. Anton Hernandez, UPM, Madrid, Spain

A.W. Bett, Fraunhofer ISE, Freiburg, Germany

V. Khorenko, AZUR SPACE, Heilbronn, Germany

R. King, Arizona State University, Tempe, USA

G. Siefer, Fraunhofer ISE, Freiburg, Germany

T. Takamoto, SHARP, Nara, Japan

G. Timò, RSE, Piacenza, Italy

Topic 5 - Operations, Performance, Reliability and Sustainability of PV

J. Binder, ZSW, Stuttgart, Germany

M. de Wild-Scholten, SmartGreenScans, Groet, Netherlands

R. Gottschalg, Loughborough University, United Kingdom

U. Jahn, TÜV Rheinland Energy, Köln, Germany

N.M. Pearsall, Northumbria University, Newcastle upon

Tyne, United Kingdom

M. Perrin, CEA, Le Bourget du Lac, France

C. Protogeropoulos, Phoenix Solar, Athens, Greece

K. Radouane, EDF EN, Paris La Defense, France

T. Sample, European Commission DG JRC, Ispra, Italy

W.G.J.H.M. van Sark, Utrecht University, Netherlands

K. Wambach, Wambach-Consulting, Aindling, Germany

C. Alonso-Tristán UBU, Burgos, Spain

M. Bächler, PerVorm, Ulm, Germany

T.R. Betts, Loughborough University, United Kingdom

P. Blanc, MINES ParisTech, Paris, France

R. Einhaus, Apollon Solar, Lyon, France

G. Friesen, SUPSI, Canobbio, Switzerland

V. Fthenakis, Columbia University, New York, USA

W.J. Gambogi, DuPont, Wilmington, USA

L. Gomes de Freitas, Federal University of Uberlândia, Brazil

G. Graditi, ENEA, Portici, Italy

M. Grottke, WIP - Renewable Energies, Munich, Germany

Y. Hishikawa, AIST, Tsukuba, Japan

T. Huld, European Commission DG JRC, Ispra, Italy

A.R. Lagunas, CENER, Sarriguren, Spain

O. Mayer, GE Global Research, Garching, Germany

M.A. Muñoz, UPM, Madrid, Spain

H. Nagel, Fraunhofer ISE, Freiburg, Germany

H. Nussbaumer, Zurich University of Applied Sciences,

Winterthur, Switzerland

C. Nyman, Soleco, Porvoo, Finland

S. Oktik, Sisecam, Istanbul, Turkey

W. Palitzsch, Loser Chemie, Zwickau, Germany

A.H.M.E. Reinders, University of Twente, Enschede,

Netherlands 
J. Remund, Meteotest, Bern, Switzerland

J.N. Roy, IIT Kharagpur, Kharagpur, India

M. Schroedter-Homscheidt, DLR, Wessling, Germany

M. Sengupta, NREL, Golden, USA

R. Sinton, Sinton Instruments, Boulder, USA

J. Sutterlueti, Gantner Instruments, Schruns, Austria

S. Tselepis, CRES, Pikermi, Athens, Greece

M. Van Iseghem, EDF R\&D, Moret-sur-Loing, France

E. Voroshazi, imec, Leuven, Belgium

A. Wade, First Solar, Berlin, Germany

J. Wohlgemuth, NREL, Golden, USA

M. Zehner, Rosenheim University of Applied Sciences, Germany

\section{Topic 6 - PV Applications and Integration}

F.P. Baumgartner, Zurich University of Applied Sciences, Winterthur, Switzerland

F. Bonemazzi, ENEL, Rome, Italy

F. Frontini, SUPSI, Canobbio, Switzerland

P. Malbranche, CEA, Le Bourget du Lac, France

A. Scognamiglio, ENEA, Portici, Italy

X. Vallvé, Trama TecnoAmbiental, Barcelona, Spain

I. Weiss, WIP - Renewable Energies, München, Germany

R. Burkhardt, Energy Depot, Kreuzlingen, Switzerland

S. Caneva, WIP - Renewable Energies, Munich, Germany

I. Da Silva, Strathmore University, Nairobi, Kenya

J.P. de Barros Duarte Fonseca, University of Cape Verde, Mindelo, Cape Verde

B. de Boer, TNO, Eindhoven, Netherlands
H. Fechner, University of Applied Sciences Technikum Wien, Breitenfurt, Austria

I.B. Hagemann, Architekturbüro Hagemann, Aachen, Germany

C. Helmke, Management Consultancy Research, Erfurt, Germany

E. Kaijuka-Okwenje, Makerere University, Kampala, Uganda

G. Mütter, Alternative Energy Solutions, Vienna, Austria

K. Peter, ISC Konstanz, Germany

T. Reijenga, BEAR-iD Sustainable Urban Planners +

Architects, Gouda, Netherlands

S. Wittkopf, HSLU, Horw, Switzerland

\section{Topic 7 - PV Economics, Markets and Policies}

C. Breyer, Lappeenranta University of Technology, Finland M. Getsiou, European Commission DG RTD, Brussels, Belgium

G. Masson, Becquerel Institute, Brussels, Belgium

T. Nordmann, TNC Consulting, Feldmeilen, Switzerland

S. Nowak, NET Nowak Energy \& Technology, St. Ursen, Switzerland

E. Perezagua, Consultores de Energía Fotovoltaica, Madrid, Spain

I. Kaizuka, RTS, Tokyo, Japan

D. Mayer, MINES ParisTech,Paris, France

P. Mazzucchelli, EUREC,Brussels, Belgium

D. Stickelberger, Swissolar, Zürich, Switzerland

S. Szabó, European Commission DG JRC, Ispra, Italy 


\title{
SUBJECT INDEX
}

\author{
New Materials and Concepts for Solar Cells and Modules \\ Sessions 1AP.1, 1AO.1, 1AO.2, 1AO.3, 1BO12, 1CO.9, 1CO.10, 1CO.11, 1BV.5, 1BV.6 \\ Wafer-Based Silicon Solar Cells and Materials Technology \\ Sessions 2BP.1, 2BO.1, 2BO.2, 2BO.3, 2BO.4, 2BO.9, 2CO.1, 2CO.2, 2CO.3, 2CO.4, 2DO.1, 2DO.2, \\ 2DO.3, 2DO.4, 2DO.16, 2AV.1, 2AV.2, 2AV.3, 2BV.7, 2DV.3 \\ Thin Film Solar Cells and Modules \\ Sessions 3CP.1, 3AO.4, 3AO.5, 3АO.6, 3BO.5, 3BO.6, 3BO.7, 3BO.8, 3CO.5, 3CO.7, 3CO.8, 3DO.9, \\ $3 C V .2,3 C V .4,3 D V .1,3 D V .2$

\section{Concentrator and Space Applications} \\ Sessions 4CP.2, 4CO.6, 4CV.1 \\ Operations, Performance, Reliability and Sustainability of PV \\ Sessions 5DP.1, 5AO.7, 5AO.8, 5AO.9, 5BO.10, 5BO.11, 5CO.13, 5CO.14, 5CO.15, 5CO.16, 5DO.10, \\ 5DO.11, 5DO.12, 5DO.15, 5EO.3, 5BV.1, 5BV.2, 5BV.3, 5BV.4, 5CV.3 \\ PV Applications and Integration \\ Sessions 6DP.2, 6CO.12, 6DO.5, 6DO.6, 6DO.7, 6DO.8, 6EO.1, 6AV.4, 6AV.5, 6AV.6, \\ PV Economics, Markets and Policies \\ Sessions 7EP.1, 7DO.13, 7DO.14, 7EO.2, 7DV.4
}

\section{Topic Code}

1 New Materials and Concepts for Solar Cells and Modules

2 Wafer-Based Silicon Solar Cells and Materials Technology

3 Thin Film Solar Cells and Modules

4 Concentrator and Space Applications

5 Operations, Performance, Reliability and Sustainability of PV

6 PV Applications and Integration

7 PV Economics, Markets and Policies

\section{Session Type}

$\mathrm{P}=$ Plenary Session

$\mathrm{O}=$ Oral Session

$\mathrm{V}=$ Visual Session

\section{Day Codes}

A = Monday, 20 June 2016

B = Tuesday, 21 June 2016

C = Wednesday, 22 June 2016

D = Thursday, 23 June 2016

$\mathrm{E}=$ Friday, 24 June 2016

e.g. 3CP.1 $\Rightarrow$ 3=Thin Film Solar Cells and Modules, C=Wednesday, P=Plenary Session, 1=Session 1 
TABLE OF CONTENT

of EU PVSEC 2016 Proceedings Papers

Subject Index

\section{New Materials and Concepts for Solar Cells and Modules}

Plenary SESSION 1AP.1 New Materials and Concepts for Solar Cells and Modules

1AP.1.2 Innovative Approaches to Interconnect Back-Contact Cells

J. Govaerts, T. Borgers, E. Voroshazi, S. Jambaldinni, B. O'Sullivan, S. Singh, M. Debucquoy, J. Szlufcik,

J. Poortmans

\section{Oral PRESENTATIONS 1AO.1 Fundamental Characterisation, Theoretical and Modelling Studies}

1A0.1.2 Transient I-V Measurement Set-Up for Photovoltaic Laser Power Converters under Monochromatic Irradiance

S.K. Reichmuth, H. Helmers, C.E. Garza, D. Vahle, M. de Boer, L. Stevens, M. Mundus, A.W. Bett, G. Siefer

1A0.1.4 Simulation-Based Optimization for Solar Cells and Modules with Novel Silver Nanowire Transparent

Electrodes

S. Altazin, R. Hiestand, M. Fontenlos, B. Ruhstaller

Oral PRESENTATIONS 1AO.2 Fundamental Materials Studies, their Characterization and Modelling

1AO.2.1 Optical Evaluation of Multi-Wire Modules

K.R. McIntosh, M.D. Abbott, M.B. Edwards, R. Evans, Y. Yao

1A0.2.2 Influence of a Very Efficient Back Reflectors on the Quantum Efficiency of Solar Cells

D.N. Micha, A. Walker, G. Siefer, F. Dimroth, A.W. Bett

1A0.2.5 A Three Dimensional Phantom Node Method to Study Complex Crack Patterns in Photovoltaic Solar Cells P.R. Budarapul, J. Reinoso, M. Paggi

\section{Oral PRESENTATIONS 1AO.3 New Materials and Concepts: Nanostructures}

1AO.3.1 Fabrication of Strain-Compensated Heterojunction Ge/Si1-xCx Quantum Dots Solar Cells K. Gotoh, R. Oshima, T. Tayagaki, T. Sugaya, K. Matsubara, M. Kondo

1A0.3.3 Thin GaAsSb Capping Layers for Improved Performance of InAs/GaAs Quantum Dot Solar Cells A.D. Utrilla, D.F. Fernández Reyes, J.M. Llorens, A. Gonzalo, I. Artacho, T. Ben, D. González, Z. Gacevic, A. Guzmán, A. Hierro, J.M. Ulloa

1AO.3.4 Influence of the Quantum Dot Capping Procedure on the Density of Defects in InAs/GaAs Quantum Dot Intermediate Band Solar Cells D.N. Micha, E.C. Weiner, R. Jakomin, L.D. Pinto, M.P. Pires, P.L. Souza

1A0.3.6 Optimizing Absorption in Resonant-Cavity-Enhanced Germanium Nanoabsorber Solar Cells for Tandem Application

V. Steenhoff, M. Vehse, C. Agert

\section{Oral PRESENTATIONS 1BO.12 Advanced Concepts for Modules}

1BO.12.2 White Bifacial Modules - Improved STC Performance Combined with Bifacial Energy Yield 


\section{PV Economics, Markets and Policies}

\section{Plenary SESSION 7EP.1 PV Economics, Markets and Policies}

7EP.1.1 True Competitiveness of Solar PV - a European Case Study

\section{Oral PRESENTATIONS 7DO.13 Contribution of PV to the Energy Transition}

7DO.13.1 On the Role of Solar Photovoltaics in Global Energy Transition Scenarios

C. Breyer, D. Bogdanov, A. Gulagi, A. Aghahosseini, L.S.N.S. Barbosa, O. Koskinen, M. Baraza, U. Caldera,

S. Afanasyeva, M. Child, J. Farfan, P. Vainikka

7DO.13.3 The Relevance of PV in the Optimisation of Synergies Among Hybrid Energy Grids in Smart Cities - the OrPHEuS Project

S. Caneva, I. Weiss, S. Betz, S. Challet, G. Heilscher, H. Ruf, D. Stakic, K. Ditz, D. Funk, F. Meier,

A. Schülke, T.G. Noh, A. Papageorgiou, S. Nicolas

7D0.13.4 Interactive Web-Service for Environmental Multi-Criteria Life Cycle Assessment of Photovoltaic Systems Worldwide

P. Perez-Lopez, I. Blanc, B. Gschwind, P. Blanc, L. Menard, R. Frischknecht, P. Stolz, Y. Durand, G. Heath

Oral PRESENTATIONS 7DO.14 PV Economics and Markets

7DO.14.1 A Snapshot of Global PV Markets - the Latest Survey Results on PV Markets and Policies from the IEA PVPS Programme 2016

G. Masson, P. Hüsser, I. Kaizuka, J. Lindahl, A. Jäger-Waldau, A. Baggini, F. Tilli, S. Guastella, P. Ahm,

G. Neubourg, J. Donoso Alonso, C. Park, V. Salas, J. Ahola

7DO.14.2 Global Photovoltaics in 2015 - Analysis of Current Solar Energy Markets and Hidden Growth Regions C. Werner, A. Gerlach, C. Breyer, G. Masson

7DO.14.4 Technical Parameters Used in PV Financial Models: Review and Analysis J. Vedde, M. Richter, C. Tjendgdrawira, B. Herteleer, M. Herz, U. Jahn, B. Stridh, L. Frearson, M. Green

7DO.14.5 Impact of Energy Storage in Conjuction With Solar PV on Wholesale Electricity Prices A. El Gammal, F. Sanches, G. Masson, H. Gouzerh, N. Gourvitch, T.M.N. Ngo

7DO.14.6 Electric Vehicles Powered with PV Electricity as a New Driver for Photovoltaics U. Muntwyler, E. Schüpbach

\section{Oral PRESENTATIONS 7EO.2 From Global Assessment to Local Deployment}

7E0.2.1 Gamifying the Energy Transition

B. O’Donnell, D. Pfahl, J. Mehling

7EO.2.2 Photovoltaic Development Standardizing Based on Roadmaps and Technology Readiness Levels P. Baliozian, S. Mourad, D. Morse, S. Kim, L. Friedrich, R. Preu

7E0.2.3 Rooftop PV Potential Estimations: Automated Orthographic Satellite Image Recognition Based on Publicly Available Data

K. Mainzer, D. Schlund, S. Killinger, R. McKenna, W. Fichtner

7EO.2.5 Pro-PV Local Building Policy - State of Progress of the Lyon-Confluence Solar City Project B. Gaiddon, M. de l'Epine, M. Valentin, E. Vignali, K. Lapray, O. Zanni 


\title{
7DO.14.1 A SNAPSHOT OF GLOBAL PV MARKETS - THE LATEST SURVEY RESULTS ON PV MARKETS AND POLICIES FROM THE IEA PVPS PROGRAMME 2016
}

\author{
Ir. Gaëtan Masson, IEA PVPS, Belgium g.masson@iea-pvps.org \\ Pius Hüsser, Nova Energie, Switzerland Pius.huesser@novaenergie.ch \\ Izumi Kaizuka, RTS Corporation, 4F 3-19-2 Hatchobori, Chuo-ku, Tokyo 104-0032, Japan, kaizuka@rts-pv.com \\ Johan Lindahl, Spokesperson, Svensk Solenergi, Holländargatan 17111 60, Sweden, johan@svensksolenergi.se \\ Arnulf Jaeger-Waldau, EC-JEC, Italy, Arnulf.JAEGER-WALDAU@ec.europa.eu \\ Angelo Baggini, Copper Alliance, Italy, angelo.baggini@unibg.it \\ Francesca Tilli, Italy, Gestore Servizi Energetici, francesca.tilli@gse.it \\ Guastella Salvatore, Italy, RSE, Salvatore.Guastella@rse-web.it \\ Peter Ahm, PA Energy, Denmark, ahm@paenergy.dk \\ Grégory Neubourg, APERE, Belgium, gneubourg@apere.org \\ José Donoso, UNEF, Spain, j.donoso@unef.es \\ Chinho Park, Yeungnam University, Korea, chpark@ynu.ac.kr \\ Vicente Salas, UC3M, Spain, vicente.salas@uc3m.es \\ Jero Ahola, LUT, Finland, jero.ahola@lut.fi \\ (on behalf of Task 1 of the IEA PVPS Programme)
}

\begin{abstract}
This snapshot report gives information on the development of PV power applications in the PVPS member and non-member countries and is largely based on the information provided by the 24 IEA PVPS countries plus the European Union through its European Commission. The report includes information on national market developments and comments about the most important changes and trends in PV support policies at the end of the former year, in this case 2015. The International Energy Agency - Photovoltaic Power System Programme (IEA PVPS)'s Task 1 is responsible for strategy and outreach within the IEA PVPS program. This includes market and industry analysis. A key deliverable of Task 1 is the annual Snapshot of Global PV Markets publication, together with the TRENDS IN PV APPLICATIONS.
\end{abstract}

This paper presents the latest survey results for the calendar year 2015 concerning PV markets and policies, as well as other key issues. An increasing number of national markets experienced notable growth in 2015 with impacts on policy development. While the final figures for 2015 will continue to be refined in the coming months, preliminary figures show that close to 51 GW of PV systems have been installed in the world last year. Some important trends observed are as follows:

- $\quad$ The global PV market grew to at least 50.7 GW in 2015, compared to around 39.7 GW in 2014 (revised figure).

- $\quad$ Asia scored the very first place again in 2015 with more than $57 \%$ of the global PV market.

- The market in Europe grew to $8 \mathrm{GW}$ for the first time in years. It has decreased significantly from 22.5 GW in 2011 to $17.5 \mathrm{GW}$ in 2012, 11 GW in 2013 and 7 GW in 2014. But in 2015 it grew for the first time in years at $8 \mathrm{GW}$.

- $\quad$ The Asia Pacific region installing close to 31 GW in 2015 has experienced the fastest market development in 2013 as well as 2014. China took the first place (with $15.2 \mathrm{GW}$ installed), ahead of Japan (10.8 GW) and the USA (7.3 GW). The first European country ranked fourth, with the $3.8 \mathrm{GW}$ installed in United Kingdom.

- In the top 10 countries, there are 3 European countries (UK, Germany and France), 5 Asia-Pacific countries (China, Japan, Korea, Australia, India), no country in Africa (South Africa installed relatively small amounts of PV in 2015) and two countries in the Americas region (USA and Canada).

- Germany, Italy and Greece have now enough PV capacity to produce respectively $\mathbf{7 . 1} \%$, 8.0 \% and $7.4 \%$ of their annual electricity demand with PV. 15 countries have enough PV to produce at least $1.3 \%$ of their electricity demand by PV.

- $\quad$ PV represents $3.8 \%$ of the electricity demand in Europe and $7 \%$ of the peak electricity demand.

- 22 countries had at least 1 GW of cumulative PV systems capacity at the end of 2015 and 7 countries installed at least $1 \mathrm{GW}$ in 2015.

\section{INTRODUCTION}

\subsection{Purpose of The Work}

The objective of the series of annual Snapshot and Trends reports - which have been published since 1992 (Trends) and 2013 (Snapshot) - is to present and interpret developments in both the PV systems and components being used in the PV power systems market and the changing applications for these products within that market. These trends are analyzed in the context of the business, policy and non-technical environment in the reporting countries.

These reports are prepared to assist those responsible for developing the strategies of businesses and public authorities, and to aid the development of medium term plans for electricity utilities and other providers of energy services. It also provides guidance to government officials responsible for setting energy policy and preparing national energy plans. Finally, it represents the most comprehensive and complete PV market analysis on a global level.

\subsection{Approach}

Key data for this publication were drawn mostly from national survey reports (up to 2014) and information summaries, which were supplied by representatives from 
each of the reporting member countries of IEA PVPS (for 2015 data). These national survey reports and the annual Snapshots can be found on the website www.iea-pvps.org. Information from the countries outside IEA PVPS are drawn from a variety of sources and, with every attempt made to ensure their accuracy.

The 24 countries currently participating in the IEA PVPS programme are Australia (AUS), Austria (AUT), Belgium (BEL), Canada (CAN), China (CHN), Denmark (DNK), Finland (FI), France (FRA), Germany (DEU), Israel (ISR), Italy (ITA), Japan (JPN), Korea (KOR), Malaysia (MYS), Mexico (MEX), the Netherlands (NLD), Norway (NOR), Portugal (PRT), Spain (ESP), Sweden (SWE), Switzerland (CHE), Thailand (THA) Turkey (TUR) and the United States of America (USA). The European Commission (EC), the Solar Power Europe association (SPE), the US Solar Electric Power Association (SEPA) and the US Solar Energy Industries Association (SEIA) and Copper Alliance are also members.

\subsection{Results And Conclusion}

Trends in photovoltaic applications is currently being compiled and the following results are based on the snapshot of global PV data collected in 2015, together with data published in National Survey Reports.

\section{MARKET DEVELOPMENT}

\subsection{Cumulative Global Installed Capacity}

The 24 IEA PVPS countries represented around 197 GW of cumulative PV installations altogether, mostly grid-connected, at the end of 2015. The other 39 countries that have been considered and are not part of the IEA PVPS programme represented 30 additional GW, mostly in Europe: UK with close to $9.1 \mathrm{GW}$, Greece with 2.6 GW, Czech Republic with $2.1 \mathrm{GW}$ installed, Romania with $1.3 \mathrm{GW}$ and Bulgaria with $1.0 \mathrm{GW}$ and below the GW mark Slovakia. Outside of Europe, the major non-IEA PVPS countries that accounted for the highest cumulative installations in 2015 were India with more than $5.1 \mathrm{GW}$, South Africa with $1 \mathrm{GW}$, Taiwan with $1 \mathrm{GW}$ and in Chile with $0.8 \mathrm{GW}$. Other countries installed significant amounts of PV but their tracking is not easy since they are not reporting official numbers. Pakistan for instance has installed around 800 MW cumulative, based on PV modules import numbers but this remains to be verified. Ukraine has also installed more than 800 MW so far, despites the losses of Crimean installations to Russia.

Meanwhile a difference of 1 or $2 \mathrm{GW}$ out of $227 \mathrm{GW}$ represents an error margin less than $2 \%$ that can be considered as scientifically acceptable. It must be noted that several countries are reporting officially AC numbers. These AC numbers refer to the theoretical output of PV systems connected to the grid, with a methodology that can differ according to the country and the segment. The correction factor to transform these AC numbers into DC numbers (that are compiled here) differs according to the country and the market segment. While for residential installations, the ratio between DC power and AC power is relatively small (and sometimes close to 1 or even below 1 in case of an inverter slightly larger than the PV installation itself, for ground-mounted installations, the ratio DC/AC can go up to 1.4 for utility-scale applications. While such a number seems high, ratios around 1.3 are mentioned by First Solar in 2016 (Annual report 2015). In that respect, AC reporting countries are mentioned below with their AC market size. Japan that reports in AC, reports also the equivalent DC number according to the Japanese grid connection regulations: 9797.4 MW AC correspond in Japan to 10811.4 MW DC.

The reporting in AC amounts to at least $40 \mathrm{GW}$ (34 GW in Japan, 5 GW in Spain, plus Canada and Austria for instance). Assuming an average correction factor of $10 \%$ instead of $15 \%$, these $40 \mathrm{GW}$ could generate a difference of 2 additional GW. These uncertainties correspond today to less than $1 \%$ of the total installed capacity. Meanwhile, it is important to consider AC and DC numbers since most tenders (for instance in Chile or UAE) consider AC number. The $200 \mathrm{MW}_{\mathrm{AC}}$ tender in Dubai that got the 58.5 USD/MWh PPA corresponds in fact to a $250 \mathrm{MW}$ DC $P$ V plant.

Finally the question of the non-reporting countries is at the core of the debate on the final numbers. In this paper, we build on data produced by a consortium of researchers (Ch. Werner \& All) that estimated the installations in non-reporting countries from this paper to $228 \mathrm{GW}$.

The figure 1 below illustrates the evolution of cumulative installed PV power in the world.

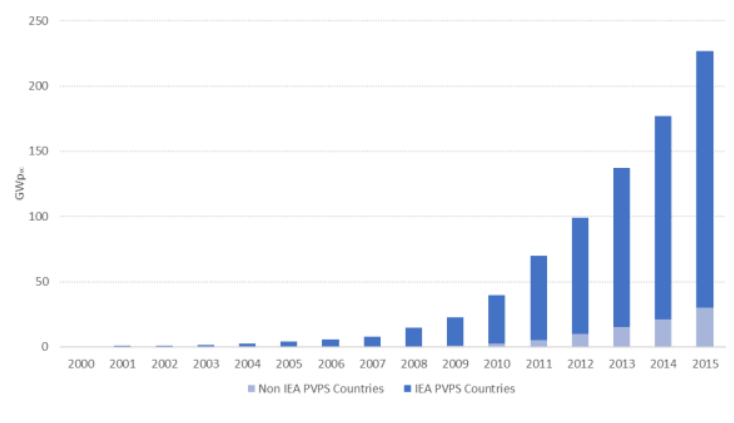

Figure 1: Cumulative installed PV power in the World (GW-DC)

\subsection{Annual Installed Capacity in 2015}

The IEA PVPS countries have installed $40 \mathrm{GW}$ of PV. While they are difficult to track with a high level of certainty, installations in non-IEA PVPS countries were pushing the installed capacity above 50 GW in 2015.

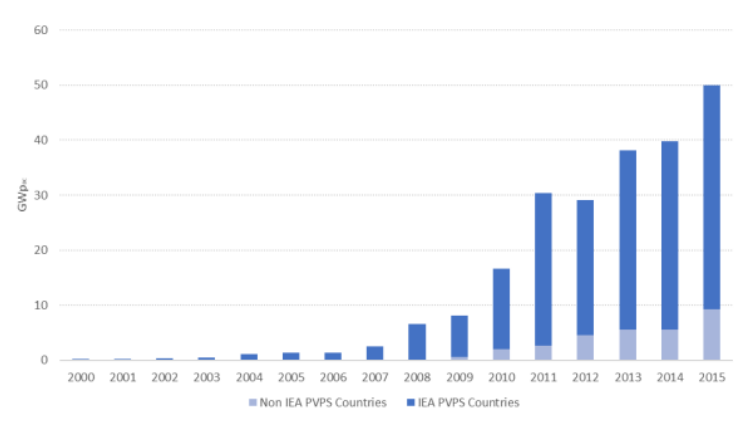

Figure 2: Annual installed PV power in the World (GW-DC) 
With around $50.7 \mathrm{GW}$, the market grew in 2015 by around 25\%, again the highest installation ever for PV. China installed 15.2 GW in 2015, according to the National Energy Administration, a record level significantly higher than the $10.6 \mathrm{GW}$ and $10.95 \mathrm{GW}$ from the last two years $(2014,2013)$ that placed the country in first place with regard to all time PV installations in 2013. This is perfectly in line with their political will to develop renewable sources and in particular PV in the short to medium term. Meanwhile more was initially planned for and the lower level reached can be explained by local difficulties to ramp up the distributed PV market and probably the beginning of rather high curtailment rates in some provinces far from consumption centers.

The second place goes to Japan for the second year in a row, with $10.8 \mathrm{GW}$ installed in the country in 2015, up from 2014 numbers. The USA installed 7.3 GW, up from 6.2 GW of PV systems in 2014, with a growing share of large utility-scale PV compared to rooftop installations.

The UK grew significantly again in 2015, becoming the first country for PV installations in Europe with 3.8 GW. The market has been powered by the rather unique set of support schemes in Europe still favoring ground-mounted installations. More than half of all 2015 installations occurred anyway in the first quarter of the year, which predicts a market decline in 2016.

India installed 2.1 GW in 2015, while a growing number of installations are reported, amidst huge expectations powered by the policy decision to install up to 100 GW before 2022 .

Together, these 5 countries represent $77 \%$ of all installations recorded in 2015, roughly the same percentage as in 2014 while the top 5 of cumulative capacities reached $70 \%$ in terms of installed capacity (China, Germany, Japan, USA, Italy).

Germany installed $1.46 \mathrm{GW}$, a major decline after the three years with PV installations around $7.5 \mathrm{GW}$, followed by 2013 at $3.3 \mathrm{GW}$ and 2014 at $1.9 \mathrm{GW}$. The total installed PV capacity in Germany is now more than 39.6 GW but the country was for the first time passed by China that became number one with more than $43 \mathrm{GW}$ of cumulative PV capacity at the end of 2015.

The following four places go to the France $(0.9 \mathrm{GW})$, Korea (1.0 GW), Australia (0.9 GW) and Canada (0.6 GW). Together these top 10 countries cover $88 \%$ of the 2015 world market, a percentage that is decreasing slowly.

Amongst countries that in the past installed significant levels of PV, Italy installed only $300 \mathrm{MW}$, down from the $9.3 \mathrm{GW}$ in 2011, 3.6 GW in 2012 and 1.7 GW in 2013. It has reached a capacity of 18.9 GW.

Several other countries where the PV market used to develop in the last years have performed in various ways: Belgium installed only $95 \mathrm{MW}$ and has now reached more than $3.2 \mathrm{GW}$. Some countries that grew dramatically over recent years have now stalled or experienced limited additions: Spain (56 MW) now totals 5.4 GWDC of PV systems followed by Czech Republic

\section{(2 MW) at $2.1 \mathrm{GW}$.}

In Europe, net-metering systems allowed the market to grow quickly in Denmark but the transition to self-consumption pushed the installations down despites a significant market improvement in 2015 (180 MW) thanks to utility-scale plants. In the Netherlands (500 MW estimated), 2015 saw significant additions while the market stabilized in Switzerland (300 MW) and in Austria (150 MW).

Malaysia installed $63 \mathrm{MW}$ for the fourth year of its Feed-in Tariff (FiT) system. Taiwan installed around 400 MW in a growing market. In Latin America, official data for Chile shows the installation of $800 \mathrm{MW}$ in two years, a first step towards PV deployment in the region. Several additional GW of PV plants have been validated in Chile, while projects are popping up in Brazil and Honduras (400 MW). The real PV development of grid-connected PV plants has finally started in the region but much more is expected in 2016, especially with the competitive tenders that have been won in Mexico, Peru or Brazil.

In the Middle East, Israel continued in a similar way (200 MW), while the PV installations in Turkey have finally started but slower than expected with around 208 MW installed in 2015. Many new projects have been announced, especially in the UAE and in Egypt and other countries are rapidly building PV plants, such as Jordan or Algeria (268 MW in 2015).

PV installations have been reported in dozens of countries in the world, with $2.3 \mathrm{GW}$ installed in non-reporting countries (source: Ch. Werner and all, op. cit.). Since this number comes mainly from imports of modules in these countries, it should be considered as the maximum maximorum. To the $40.7 \mathrm{GW}$ in IEA-PVPS countries, $7.7 \mathrm{GW}$ can be added in other countries where PV installations are followed properly (those mentioned in this document with installation numbers) and $2.3 \mathrm{GW}$ additional installations, pushing the 2015 installations numbers up to $50.7 \mathrm{GW}$.

\subsection{Shift to Asia}

While Europe represented a major part of all installations globally in 2011, the share of Asia and America started to grow rapidly from 2012, with Asia taking the lead. This evolution is quite visible from 2011 to 2014, with the share of the Asia Pacific region growing from $18 \%$ to close to $60 \%$ in 2014 and 2015, whereas the European share of the PV market went down from $74 \%$ to $15 \%$ in five years. This trend shows that the development of PV globally is no longer in the hands of European countries but rather has become global, powered by the demand for electricity and the population per region rather than only policy decisions.

Finally, the share of the PV market in the Middle East and in Africa remains relatively small compared to other regions of the world, despite the growth of the South African market and the numerous projects in UAE or Egypt.

\subsection{Utility-scale PV in progress}

The evolution of grid-connected PV towards a balanced segmentation between centralized and 
decentralized PV has reversed course in 2013 and continued its trend in 2014 and 2015: centralized PV has evolved faster and most of the major PV developments in emerging PV markets are coming from utility-scale PV. Globally, centralized PV represented more than $60 \%$ of the market in 2015, mainly driven by China, the USA, and emerging PV markets.

In 2014, utility-scale represented more than $55 \%$ of the market and $64 \%$ in 2015 (32.6 GW out of $50.7 \mathrm{GW}$ ). Prospects for the coming years are going in the same direction with many countries targeting large-scale ground-mounted PV (Brazil, Chile, South-Africa, Indonesia...). Europe was in 2015 the only region where the share of distributed PV was higher than centralized in 2015 and higher than 50\%. Moreover distributed installations have stagnated in 2015 compared to 2014 in absolute terms (18 GW compared to $19 \mathrm{GW}$ ) and declined significantly in relative terms.

\section{$3 \quad$ POLICY FRAMEWORK}

PV development over the last ten years has been powered by the deployment of support policies, aimed at reducing the gap between PV's cost of electricity and the price of conventional electricity sources. These support schemes took various forms depending on the local situations and evolved to cope with unexpected market evolution or policy changes. The figure 3 below shows that only $0.2 \%$ of the world PV market has been driven by pure self-consumption or the sole competitiveness of PV installations in 2015. Tenders granting PPAs have represented less than $6 \%$ of the new PV capacities in 2015. Self-consumption represented, together with similar schemes such as net-billing or net-metering close to $15 \%$ of the new installations. It also means $78.3 \%$ of the global PV market depends on financial support schemes. In 2014 and 2015 a large part of the market remained dominated by FiT schemes (more than 59\%) outside of tendering processes. Subsidies aiming at reducing the upfront investment (or tax breaks) represent around $16 \%$ of the incentives. Incentivized self-consumption including net-billing and net-metering was the main incentive in 2015 for $16 \%$ of the world market. Various forms of incentivized self-consumption schemes exist, such as in Italy with the Scambio Sul Posto, Israel, or Germany.

The emergence of calls for tenders has been confirmed again in 2015, with new countries using this legal tool to attribute remunerations to PV projects under certain conditions. Germany, France, Peru, Brazil, Mexico, Dubai (UAE), Jordan and many others have joined the list of countries using calls for tenders to grant PPAs for PV plants. The result of these calls for tenders is a guaranteed payment for PV electricity, or in other words, a FiT. Such tenders represented around $5.6 \%$ of the world market in 2015 and is increasing.

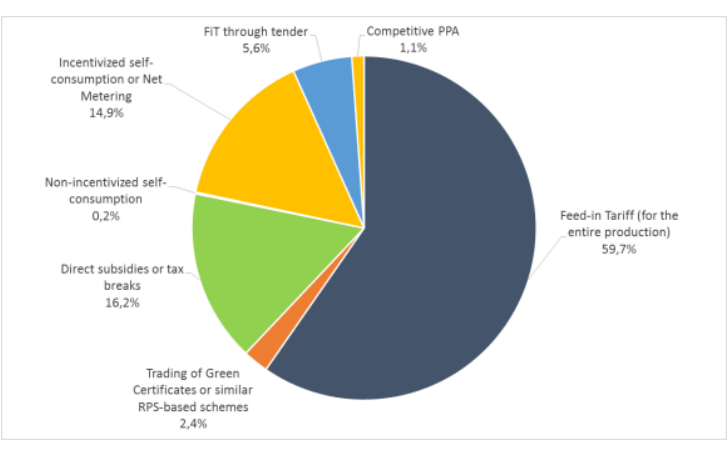

Figure 3: Market Incentives and Enablers in 2015

Historically the dominance of feed-in tariffs and direct subsidies is similar but even more visible in Figure 6 that compiles installations until the end of 2014. Incentives can be granted by a wide variety of authorities or sometimes by utilities themselves. They can be unique or add to each other. Their lifetime is in general quite short, with frequent policy changes, at least to adapt the financial parameters. Next to central governments, regional states or provinces can propose either the main incentive or some additional ones. Municipalities are more and more involved in renewable energy development and can offer additional advantages. In some cases, utilities are proposing specific deployment schemes to their own customers, in general in the absence of national or local incentives.

\section{HISTORICAL MARKET INCENTIVES AND ENABLERS}

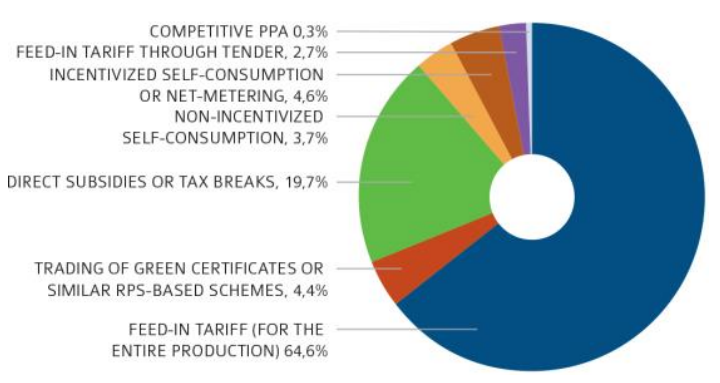

Figure 4: History of PV market drivers and Enablers until 2014 (IEA-PVPS Trends report 2015)

\section{PV IN THE POWER SECTOR}

Figure 5 shows how PV theoretically contributes to the electricity demand in the IEA PVPS countries, based on the PV base at end 2015. Italy remains the number one country with $8 \%$ of its electricity that will come from PV in 2016 based on 2015 total level of installations. This number can be translated into 15 to $16 \%$ of the peak electricity demand.

In Germany, with more than $6.7 \%$, the $39.7 \mathrm{GW}$ installed in the country produce up to $50 \%$ of the instantaneous power demand on some days, and around $13 \%$ of the electricity during the peak periods. Several countries outside the IEA PVPS network have the ability to produce significantly more than $3 \%$ of their electricity demand: Honduras (not featured in the figure below) with $12 \%$ of its electricity demand, Greece (around $7.6 \%$ based on the 2014 installed capacity), Bulgaria and the Czech Republic. Spain remains below the $4 \%$ mark as 
well as Belgium, which is producing $3.6 \%$ of its electricity thanks to PV. Romania, Japan, Australia, Switzerland, Slovenia and Israel are above the $2 \%$ mark. Denmark and the UK are approaching the 2\% mark, while Austria, France, Portugal and Chile are still below the $1.5 \%$ mark. Thailand and the Netherlands passed the $1 \%$ of the electricity demand mark in 2015. Many other countries have lower production numbers.

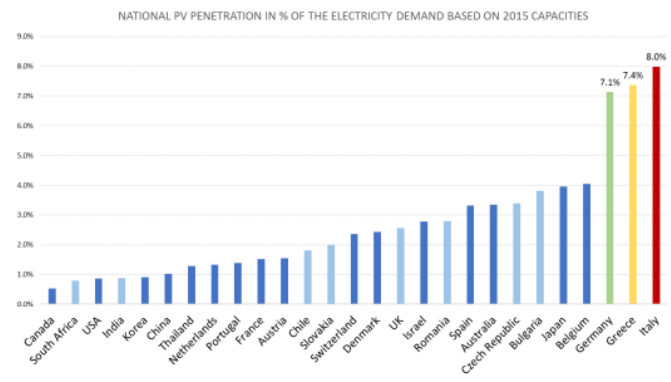

Figure 5: Theoretical PV production share by country based on 2015 cumulative installed capacity.

\section{CONCLUSION}

The year 2015 experienced a renewed growth of the PV market and confirmed the Asian leadership on the PV market and industry. PV is entering rapidly into a new era where the PV market will be concentrated in countries with energy needs. Two of the top three markets in 2015 were located in Asia (China and Japan), followed by Europe as a whole and the US PV market. This trend should be confirmed again in 2016, with Asia consolidating the core of the PV market, followed by the Americas and Europe, while India is going to modify these results in the coming years.

The challenges are still numerous before PV can become a major source of electricity in the world. The way how distribution grids could cope with high shares of PV electricity, generation adequacy and balancing challenges in systems with high shares of variable renewables, the evolution of energy storages technologies and the cost of transforming existing grids will be at the cornerstone of PV deployment in the coming years. Moreover, the ability to successfully transform electricity markets to integrate PV electricity in a fair and sustainable way will have to be scrutinized.

The road to PV competitiveness is open but remains complex and linked to political decisions. Nevertheless, the assets of PV are numerous and as seen in this edition of the IEA PVPS Snapshot report, the appetite for PV electricity grows all over the world. The road will be long before PV will represent a major source of electricity in most countries, but as some European countries have shown in recent years, PV has the ability to continue progressing fast.

\section{REFERENCES}

1. 2014 National Survey reports of IEA-PVPS countries, on www.iea-pvps.org

2. 2015 IEA-PVPS Trends in PV Applications

3. IEA-PVPS Snapshot of Global PV Markets 2015

4. GLOBAL PHOTOVOLTAICS in 2015, analysis of current solar energy markets ANd Hidden growth regions, Ch. Werner, A. Gerlach, Ch. Breyer, G. Masson, 2016, $32^{\text {nd }}$ EU-PVSEC 